\title{
Determination of Association between Duration of Labour and Some Social Status Using Chi-Square Distribution $\left(\chi^{2}\right)$
}

\section{Peter $\mathrm{O}^{*}$ and lornongo AG}

Mathematics/Statistics/Computer Science Department, Federal University of Agriculture, Nigeria

\begin{abstract}
A sample of two hundred and seventy (270) women based on child delivery were randomly selected from General Hospital North-Bank Makurdi, Benue State. Data was analyzed using Chi-square (X2) test of independence using SPSS Version 20. The result shows that Multiparous are most likely to have shorter labour durations that is between $0-4$ hours than Primiparous women and both have equal chance of having prolonged duration of labour in Makurdi local government area of Benue State at $29.6 \%$ and $15.9 \%, 8.9 \%$ and $8.9 \%$ respectively. Multiparous women are most likely to present at the second stage of labour with a total of $30.0 \%$ than Primiparous women. Most Primiparous women with a total of $27.8 \%$ are most likely to present at first stage of labour. There is no association between Duration of labour and Social Status of women in Makurdi local government area of Benue State. However, the duration of labour is significantly associated with the stage of presentation of delivering women hence the higher the parity the shorter the duration of labour.
\end{abstract}

Keywords: Primipara; Nulliparous; Multiparous; Primigravida; Multigravida; Caesarean section

\section{Introduction}

The study of statistics has enhanced the growth of our everyday life activities and has given us the privilege to be able to estimate, evaluate, and predict the outcome of the future and the significance differences between two entities by data collection.

With the help of statistics the collection of data on the duration of labour has been made possible. For instance, the World Health Organization report (WHO 2010) [1] reports that in 2008, an estimated 358,000 women died due to complications developed during pregnancy and childbirth. One out of every 31 women dies during pregnancy or childbirth in sub-Saharan Africa, compared with just one in 4,200 in Europe. For every woman who dies, at least 20 more suffer injury, infection or disability from maternal causes; approximately seven million women every year. This was possible through the use of statistics.

Child birth is a vital human experience and tool for human existence. It is shaped by the society in which the birthing woman resides as such childbirth and its management occur within the social consideration of the event [2].

Ensminger and Fothergill [3] are of the opinion that each of these markers of social status demonstrates different levels of stability across time and differentially predicts family processes. Education is one of the most widely used indicators of socio economic status and is seen by many to be the crux element of socio economic status since it has significant influence on income and occupation. This is also supported by Krieger et al. [4] that income, education, and occupational status are sometimes used together as indicators of social status and also as separate variables in data analysis so that investigators can evaluate their unique, additive contributions to family characteristics and human development. Aboyeji and Fawole [5] opines that labour problems are rare events in developed countries of the world but a common obstetric problem in developing countries due to socio economic problems such as wide spread poverty, ignorance, poor transport system, lack of proper educational system, belief in home deliveries, fear and aversion of surgery. These problems are not different within Makurdi local government Area of Benue State as such a more broad based approach must be taken to reduce this scourge.

There has been a global outcry about the high rate of maternal and neonatal mortality and morbidity. Labour duration as it relates to the social status of the mother is not known and hence many mothers die during delivery and at the same time may have gone into caesarean section when they are not supposed to because of insufficient knowledge at their disposal. We are interested to know if there exist an association between the duration of labour and the social status of delivering women using chi-square.

The total of 135 million births were recorded globally in 2015 (world fact book 2016) but in the developed world most deliveries occur in hospital Olsen and Clausen (2012) while in the developing countries most births take place at home with the support of a traditional birth attendant Fossard et al. [6]. Childbirth, also known as labour and delivery, is the ending phase of a pregnancy where by one or more babies leaves a woman's uterus.

Labour duration, in hours, is an outcome variable which can be defined as starting from active phase of labour; $3-4 \mathrm{~cm}$ cervical dilatation and three uterine contractions per 10 minutes lasting greater or equal to one $(\geq 1)$ minute, until delivery of the child Blix et al. [7]. Most women arrived at the hospital after commencement of the active phase of labour. The most common way of childbirth is a vaginal delivery. Labour has three (3) main stages (first, second and Third stage) characterized by the shortening and opening of the cervix (goes from being closed to fully open (10 cm dilated)), pushing and birth of the baby, and the dropping out of the placenta.

${ }^{*}$ Corresponding author: Peter O, Mathematics/Statistics/Computer Science Department, Federal University of Agriculture, Nigeria, Tel: +234 (0)8058943244; E-mail: ptrnch@yahoo.co.uk

Received July 27, 2017; Accepted September 28, 2017; Published October 11 2017

Citation: Peter O, lornongo AG (2017) Determination of Association between Duration of Labour and Some Social Status Using Chi-Square Distribution $\left(\chi^{2}\right)$. J Biom Biostat 8: 372. doi: 10.4172/2155-6180.1000372

Copyright: ( 2017 Peter O, et al. This is an open-access article distributed under the terms of the Creative Commons Attribution License, which permits unrestricted use, distribution, and reproduction in any medium, provided the original author and source are credited. 
The first stage typically lasts twelve (12) to nineteen (19) hours. The second stage twenty minutes to two (2) hours, and the third stage five to thirty minutes [1].

In the third stage delayed clamping of the umbilical cord is generally recommended McDonald et al. [8]. According to WHO, each year women encounter pregnancy related complications from childbirth result in about 500,000 maternal deaths, 7 million serious long term problems, and 50 million health related negative outcomes from delivery, most of these occur in the developing countries. Furthermore, Specific complications include prolonged or obstructed labour, postpartum bleeding, eclampsia, and postpartum infection. UNICEF revealed that a woman's chance of dying from pregnancy and childbirth in Nigeria is 1 to 13. In addition, World Health Organization (WHO) [1] recently reported that the 'Trends in maternal mortality from 1990 to 2013' classified Nigeria as one of the 10 countries of the world that contribute about 60 per cent of the world's maternal mortality burden.

The duration of the second stage of birth (labour and delivery) differs by factors including the number of children a woman has had, the presence of infection, fetal size and anesthesia. Longer labour duration are associated with declining rates of spontaneous vaginal delivery and increasing rates of infection, perinea laceration, and obstetric hemorrhage, as well as the need for intensive care of the patient [9].

According to Praneer [10] the choices of doctors and places of birth are clearly dictated by the women's social positions. Middle class women have more financial resources to enable them actively to seek care from private doctors who can give them more attention. Rural poor women have fewer choices in where they should give birth, the type of doctors they can see and of the hospitals that cater for their needs. This may also contribute to their silence, as they may not feel empowered enough to make their voice heard.

Ochejele [11] stated that one the major challenge of labour management is the delayed involvement of senior medical personnel due to poor awareness of basic labour and delivery indicators in health facilities. Considering the variation that occurs in the duration of labour, 3 to 12 hours are consider to be a normal acceptable period. Labour lasting less than 3 hours is termed precipitate while those that exceeding 12 hours is said to be prolonged Orhue and Otubu [12].

Normal labour is divided into three stages the first stage of labour is the interval between the onset of labour to full cervical Os dilation, the second stage which is the interval between full cervical Os dilation to delivery of the fetus/neonate and the third stage of labour is the period between the delivery of the neonate and the delivery of the placenta. It is important that a woman receives good intrapartum care for all the three stages of labour. A woman presenting in second stage of labour will not benefit fully from intrapartum care, since she has not been monitored by an expert during the first stage of labour. In recent times, antenatal care has reduced remarkably maternal and perinatal complications; however, these benefits may not be fully utilized if the women do not receive good intra partum care Michael et al. [13].

Duration of labour is affected by various maternal and fetal factors including maternal age, parity, maternal pain threshold, number of fetuses, fetal weight and fetal position and dystocia. It is also affected by interventions like induction of labour, augmentation of labor and instrumental vaginal deliveries. Misdiagnosis of these complications has contributed to increase in cesarean section rate [14]

\section{Material and Method}

In this paper, we are interested in studying the association between duration of labour and social status of 270 women with intended vaginal delivery in medical records department of General Hospital North-bank Makurdi using Chi-square $\left(\chi^{2}\right)$ statistic which is one of non-parametric test of significance used with discrete data in form of frequencies counts. It is a test of independence and is used to estimate the likelihood that some factor other than chance accounts for observed relationship and hence suitable for this research work.

A random variable has a chi-square distribution with $\mathrm{N}$ degrees of freedom if it has the same distribution as the sum of the squares of $\mathrm{N}$ independent variables, each Categorical Data Analysis is normally distributed, and each having expectation 0 and variance 1 .

$$
\begin{aligned}
& \text { If } \mathrm{Z} \sim \mathrm{N}(0,1) \text {, then } \mathrm{Z}^{2} \sim \text { Chi-square } \\
& \text { If } \mathrm{Z}_{1} \text { and } \mathrm{Z}_{2} \text { both } \sim \mathrm{N}(0,1) \text {, then } \mathrm{Z}_{1}^{2}+\mathrm{Z}_{2}^{2} \sim \text { Chi-square }
\end{aligned}
$$

The calculation of chi-square $\left(\chi^{2}\right)$ involves comparing observed and expected frequencies of variable $\mathrm{X}$ and $\mathrm{Y}$ using the formula below:

$$
\chi^{2}=\sum_{\mathrm{i}=1}^{\mathrm{r}} \sum_{\mathrm{j}=1}^{\mathrm{c}} \frac{\left(\mathrm{O}_{\mathrm{ij}}-\mathrm{E}_{\mathrm{ij}}\right)^{2}}{\mathrm{E}_{\mathrm{ij}}}
$$

Where:

$\chi^{2}$ : The test statistic that asymptotically approaches a chi-square distribution.

$\mathrm{O}_{\mathrm{ij}}$ : The observed frequency of the ith row and $\mathrm{jth}$ column $=\left(\mathrm{X}_{\mathrm{i}} \mathrm{Y}_{\mathrm{j}}\right)$.

$E_{i j}$ : The expected (theoretical) frequency of the ith row and jth column which is given by the formula:

$$
E_{i j}=\frac{\operatorname{Row} \operatorname{Total}\left(\mathrm{X}_{\mathrm{i}}\right) \times \operatorname{Column} \operatorname{Total}\left(\mathrm{Y}_{\mathrm{j}}\right)}{\operatorname{Grand} \operatorname{total}(\mathrm{N})}
$$

This is calculated by first obtaining the columns totals and grand total for the observed frequencies in the contingency table and calculating the expected frequencies $\left(\mathrm{E}_{\mathrm{ij}}\right)$ for the table which is gotten by the formula in eqns. (3) and (4).

Also we define the degrees of freedom (d.f) for the contingency table in the test. This is computed using the formulas below:

If there is one independent variable the d.f $=(\mathrm{c}-1)$

If there are two independent variables the $\mathrm{d} . \mathrm{f}=(\mathrm{r}-1)(\mathrm{c}-1)$

Where:

r: The number of rows in the contingency table,

c: The number of columns in the contingency table.

These formulas must be used in line with the assumption/ restrictions on the use of chi-square test in contingency tables.

\section{Results}

The data collected were at nominal and ordinal scale of measurement hence we used absolute numbers, frequency counts and simple percentages were used to describe categorical variables. Labor duration in hours were grouped into four-categories as follows: 0 to 4 hours, 5 to 8 hours, 9 to 12 hours and 13 hours and above since labor durations from 4 to 12 hours are normal while that exceeding 12 hours 
Citation: Peter O, lornongo AG (2017) Determination of Association between Duration of Labour and Some Social Status Using Chi-Square Distribution $\left(\chi^{2}\right)$. J Biom Biostat 8: 372. doi: 10.4172/2155-6180.1000372

Page 3 of 5

is considered prolonged. Labour durations and Social Status of two hundred and seventy (270) women who had given birth at the General Hospital North bank Makurdi were randomly selected for a period of three years (2014 to 2016) (Tables 1 and 2).

This section focuses on the use of chi-square Statistic and interpretation of tables will equally be given in this section. We present the result of Chi-square test of association between duration of labor and Social Status (Employed and Unemployed) women with a view of testing the Chi-square test.

Using $\chi^{2}$ calculated which is less than the tabulated, and also the p_value of 0.150 is greater than alpha level of 0.05 , we accept $\mathrm{H}_{0}$ and conclude that the duration of labuor is not associated with Employment status of delivering women at $5 \%$ level of significance (Table 3).

For that of duration of labour with Married and Unmarried women in Table 4 below, we found out that the duration of labour is not associated with marital status of delivering women Since $\chi_{\text {cal }}^{2}=7.050<\chi_{\text {tab }}^{2}=7.81$ ( $p$ value of $0.070>$ alpha level of 0.05 ) and hence reject the alternative hypothesis that there is an association between the labour duration and marital status at $5 \%$ level of significance.

The result of Chi-square test of Association between duration of labour and Age distribution of delivering women is given with a view of achieving the Hypothesis that; testing the hypothesis that the duration of labour is not associated with age distribution of delivering women against the duration of labour is associated with age distribution of delivering women at $5 \%$ level of significance.

From Table 5, we accept $\mathrm{H}_{0}$ and conclude that the duration of labour is not associated with Age distribution of delivering women at $5 \%$ level of significance since $\chi^{2}{ }_{\text {cal }}=0.067 \leq \chi_{\text {tab }}^{2}=7.81$ ( $\mathrm{p}$ value of $0.995>0.05)$.

The duration of labour is not associated with the parity of delivering women against the duration of labour is associated with the parity of delivering women using $5 \%$ alpha level of significance. The $p$ value of $0.297>0.05$ alpha level of significance, then we accept $\mathrm{H}_{0}$ and conclude

\begin{tabular}{|c|c|c|c|c|c|c|}
\hline \multirow[t]{2}{*}{ Duration of labor } & \multicolumn{2}{|c|}{ Employment Status of women } & \multicolumn{2}{|c|}{ Employment Status of Husband } & \multicolumn{2}{|c|}{ Marital Status } \\
\hline & Employed & Unemployed & Employed & Unemployed & Married & Unmarried \\
\hline $0-4 \mathrm{~h}$ & 28 & 95 & 93 & 28 & 102 & 21 \\
\hline $5-8 \mathrm{~h}$ & 8 & 62 & 51 & 22 & 50 & 20 \\
\hline $9-12 \mathrm{~h}$ & 6 & 23 & 21 & 7 & 19 & 10 \\
\hline 13 and above & 10 & 38 & 28 & 20 & 33 & 15 \\
\hline Total & \multicolumn{2}{|c|}{270} & \multicolumn{2}{|c|}{270} & \multicolumn{2}{|c|}{270} \\
\hline
\end{tabular}

Table 1: Distribution of duration of labour and Social Status of women from 2014-2016.

\begin{tabular}{|c|c|c|c|c|c|c|c|}
\hline \multirow[t]{2}{*}{ Duration of labor } & \multicolumn{2}{|c|}{ Age Distribution } & \multicolumn{3}{|c|}{ Parity } & \multicolumn{2}{|c|}{ Parity } \\
\hline & $15-30$ & $31-46$ & Primiparous & Multiparous & Stage & Primipara & Multipara \\
\hline $0-4 \mathrm{~h}$ & 97 & 26 & 43 & 80 & - & - & - \\
\hline $5-8 h$ & 55 & 16 & 29 & 41 & 1st stage & 75 & 82 \\
\hline $9-12 \mathrm{~h}$ & 22 & 6 & 10 & 19 & - & - & - \\
\hline 13 and above & 38 & 10 & 24 & 24 & 2nd stage & 32 & 81 \\
\hline Total & \multicolumn{2}{|c|}{270} & \multicolumn{2}{|c|}{270} & & \multicolumn{2}{|c|}{270} \\
\hline
\end{tabular}

Table 2: Distribution of duration of labour and demographic factors of women from 2014-2016.

\begin{tabular}{|l|c|c|}
\hline & Value & Asymp. Sig. (2-sided) \\
\hline Pearson Chi-square & $5.324^{\text {a }}$ & 3 \\
\hline Likelihood ratio & 5.491 & 3 \\
\hline Linear-by-linear association & 0.293 & 15 \\
\hline N of valid cases & 270 & 0.139 \\
\hline a1 cells $(125 \%)$ have expected count less than 5. The minimum expected count is 3.85. & 0.588 \\
\hline
\end{tabular}

a 1 cells $(12.5 \%)$ have expected count less than 5 . The minimum expected count is 3.85 .

Table 3: Chi-square test

\begin{tabular}{|l|c|c|}
\hline & Value & Asymp. Sig. (2-sided) \\
\hline Pearson Chi-square & $7.050^{\mathrm{a}}$ & 3 \\
\hline Likelihood ratio & 7.143 & 3 \\
\hline Linear-by-linear association & 5.374 & 0.70 \\
\hline N of valid cases & 270 & 0.067 \\
\hline a 0 cells $(0.0 \%)$ have expected count less than 5. The minimum expected count is 7.09. & 0.020 \\
\hline
\end{tabular}

Table 4: Chi-square test.

\begin{tabular}{|l|c|c|}
\hline & Value & Asymp. Sig. (2-sided) \\
\hline Pearson Chi-square & $.067^{\text {a }}$ & 3 \\
\hline Likelihood ratio & 0.067 & 3 \\
\hline Linear-by-linear association & 0.001 & 1 \\
\hline N of valid cases & 270 & 0.995 \\
\hline
\end{tabular}

${ }^{a} 0$ cells $(0.0 \%)$ have expected count less than 5 . The minimum expected count is 6.01

Table 5: Chi-square tests 


\begin{tabular}{|l|c|c|}
\hline & Value & Asymp. Sig. (2-sided) \\
\hline Pearson Chi-square & $3.691^{\text {a }}$ & 3 \\
\hline Likelihood ratio & 3.655 & 3 \\
\hline Linear-by-linear association & 2.454 & 0.297 \\
\hline N of valid cases & 270 & 0.301 \\
\hline${ }^{a} 0$ cells $(0.0 \%)$ have expected count less than 5. The minimum expected count is 11.39. & 0.117 \\
\hline
\end{tabular}

${ }^{a} 0$ cells $(0.0 \%)$ have expected count less than 5 . The minimum expected count is 11.39 .

Table 6: Chi-square tests.

\begin{tabular}{|c|c|c|c|c|c|}
\hline & & & Parity Primiparous women & Multiparous women & Total \\
\hline \multirow[t]{6}{*}{ Stage of presentation } & \multirow[t]{3}{*}{$1^{\text {st }}$ stage } & Count & 75 & 82 & 157 \\
\hline & & Expected Count & 62.2 & 94.8 & 157 \\
\hline & & $\%$ of Total & $27.80 \%$ & $30.40 \%$ & $58.10 \%$ \\
\hline & \multirow[t]{3}{*}{$2^{\text {nd }}$ stage } & Count & 32 & 81 & 113 \\
\hline & & Expected Count & 44.8 & 68.2 & 113 \\
\hline & & $\%$ of Total & $11.90 \%$ & $30.00 \%$ & $41.90 \%$ \\
\hline \multirow[t]{3}{*}{ Total } & \multirow[t]{3}{*}{$3^{\text {rd }}$ stage } & Count & 107 & 163 & 270 \\
\hline & & Expected Count & 107 & 163 & 270 \\
\hline & & $\%$ of Total & $39.60 \%$ & $60.40 \%$ & $100.00 \%$ \\
\hline
\end{tabular}

Table 7: Stage of presentation Primiparous and Multiparous delivering women.

\begin{tabular}{|l|c|} 
& Value \\
\hline Pearson Chi-Square & 10.392 \\
\hline Likelihood Ratio & 10.582 \\
\hline Linear-by-Linear Association & 10.354 \\
\hline $\mathrm{N}$ of Valid Cases & 270 \\
\hline
\end{tabular}

\begin{tabular}{|c|c|c|}
\hline Value & df & Asymp. Sig. (2-sided) \\
\hline $10.392^{\mathrm{a}}$ & 1 & 0.001 \\
\hline 10.582 & 1 & 0.001 \\
\hline 10.354 & 1 & 0.001 \\
\hline 270 & & \\
\hline
\end{tabular}

cells $(0.0 \%)$ have expected count less than 5 . The minimum expected count is 44.78

${ }^{\mathrm{b}}$ Computed only for a $2 \times 2$ table.

Table 8: Chi-square tests ${ }^{\mathrm{b}}$.

\begin{tabular}{|l|c|c|c|}
\hline & & Value & Approx. Sig. \\
\hline Nominal by nominal & Phi & 0.196 & 0.001 \\
\cline { 2 - 4 } & Cramer's V & 0.196 & 0.001 \\
\hline N of valid cases & & \multicolumn{2}{|c|}{270} \\
\hline
\end{tabular}

Table 9: Symmetric measures.

that the duration of labour is not associated with the Parity of delivering women (Table 6).

From Table 7, 15.9\% were primiparous and 29.6\% multiparous with a total of $45.6 \%$ of women had labour durations ranging from 0 to 4 hours (Precipitate labuor). $14.4 \%$ primiparous and $18.9 \%$ were multiparous women with a total of $36.6 \%$ of women had labour durations from 5 to 12 hours (normal labor). $8.9 \%$ primiparous and $8.9 \%$ multiparous women with a total of $17.8 \%$ had durations 13 hours and above. It can also be seen that $39.3 \%$ of the women were Primipara and $60.7 \%$ were Multipara. Hence multiparous are most likely to have precipitate labour than premiparous women. Hence the higher the parity the shorter the labour hours (Table 8).

Using the $\chi_{\text {cal }}^{2}=10.392>\chi_{\text {tab }}^{2}=3.84$ or using the probability value ( $p$ value of $0.001<0.05$ alpha level) therefore, we reject $\mathrm{H}_{0}$ and conclude that the duration of labour is significantly associated with the stage of presentation of delivering women at $5 \%$ level of significance. In addition, there is an evidence of independence between time of delivery and stage of presentation since both Cramer's $\mathrm{V}$ and $\mathrm{Phi}=0.196$ and are significant (Table 9).

From Table 7, 27.8\% were Primiparous and 30.4\% Multiparous with a total of $58.1 \%$ of women presented at the $1^{\text {st }}$ stage of labour. $11.9 \%$ Primiparous and $30.0 \%$ were Multiparous women with a total of $41.9 \%$ presented at the $2^{\text {nd }}$ stage of labour. It can also be seen that $39.6 \%$ of the women were Primipara and $60.4 \%$ were Multipara.
Hence Multiparous women are most likely present at the second stage of labour than Premiparous women. Most Premiparous women with a total of $27.8 \%$ are most likely to present at first stage of labour. There is an association between stage of presentation and parity of women in the study area.

\section{Conclusion}

We observed that $35.2 \%$ of Unemployed women in Makurdi local government area are more prone to have precipitate labour and a $17.4 \%$ chance of having longer labour hours than their employed counterparts with a $10.4 \%$ and $3.7 \%$ respectively.

Since Unemployed women in the local government constitute the highest percentage of $80.7 \%$ this shows a high dependence on their husbands for financial support and decision making which can affect their choice of maternal healthcare service and time of presentation.

We also saw that married women are more prone to have both shorter labour hours and prolonged labor than their unmarried counterpart.

$35.9 \%$ of women aged $15-30$ are more prone to have shorter and longer labour hours than those aged 31-46 and more births occurs within the ages of 15-30 years.

It can be seen that the higher the parity the shorter the duration of labour which is as a result of experiences gather over the years. Hence Multiparous are most likely to have shorter labour hours than Primiparous women. In addition, Multiparous women are most likely to present at the second stage of labour than Premiparous women.

From results, we summarizes that there is no association between duration of labour and Social Status of women in Makurdi local 
Citation: Peter O, lornongo AG (2017) Determination of Association between Duration of Labour and Some Social Status Using Chi-Square Distribution $\left(\chi^{2}\right)$. J Biom Biostat 8: 372. doi: 10.4172/2155-6180.1000372

government area of Benue state but However, the duration of labour is significantly associated with the stages of presentation of delivering women.

\section{References}

1. Women's Health Organization (2010) Pregnancy labor and Birth.

2. Liamputtong RP, Manderson L (1996) Maternity and Reproductive Health in Asian Societies. Amsterdam: Harwood Academic Press.

3. Ensminger ME, Fothergill KA (2003) Decade of measuring SES: What it tells us and where to go from here.

4. Krieger N, Williams DR, Moss N (1997) Measuring social class in US. Public health research: Concepts, methodologies, and guidelines. Annual Review of Public Health 18: 341-378.

5. Aboyeji AP, Fawole AA (1999) Obstructed labor in Ilorin, Nigeria a one year Prospective Study. University of llorin Teaching Hospital Maternity Wing Ilorin Nigeria. Nigerian Medical Practioner 38: 1-3.

6. Fossard E, Bailey M (2016) Communication for Behavior Change: Using Entertainment- Education for distance education. Sage publications India.

7. Blix E, Kumle M, Oian P (2008) What is the duration of normal labour? Norwegian. Tidsskr Nor Laegeforen 128: 686-689.
8. McDonald SJ, Middleton P, Dowswell T, Morris PS (2013) Effect of timing of umbilical cord clamping of term infants on maternal and neonatal outcomes. The Cochrane database of systematic reviews.

9. Rouse DJ, Weiner SJ, Bloom SL, Varner MW (2009) Second stage labour duration in nulliparous women: Relationship to maternal and perinatal outcome. American Journal of Obstetrics and Gynecology 201: 357.

10. Praneer L (2005) Birth and Social Class; Northern Thai women's lived experience of Caesarean and vaginal birth.

11. Ochejele S (2013) Basic Indices for Labor and Delivery Management in Nigeria Department of Obstetrics and Gynaecology Federal Medical Center Markudi, Nigeria, Trop J Obstet Gynaecol 30 (1).

12. Orhue AA, Otubu JA (2006) Prolonged labour. In: Aeditor A (ed.) Textbook of Obstetrics and Gynaecology for medical students. (2ndedn), Heinemann educational books Ibadan, pp: 439-441.

13. Michael TM, Patric HD, Victor CPM, Terrumum ZS, Augustine OO, et al. (2016) Labour outcome in patients admitted in the second stage of labour at Jos University Teaching Hospital. Jos, Nigeria.

14. Munir'deen Al, Kike TA, Hadijat OR, Abiodun PA, AbdulWaheed OO, et al (2011) Duration of labor with spontaneous onset at the University of Ilorin Teaching Hospital, llorin, Nigeria. Annals of African Medicine 10. 